\title{
The Effect Of Short-Term Debt On Accrual Based Earnings Management And Real Earnings Management
}

\author{
Sun-young Park, Kyungpook National University, South Korea
}

\begin{abstract}
This study investigates whether short-term debt is related to earnings management. Short-term debt is divided into total current liabilities, debt in current liabilities and short-term borrowings. In addition, this study examines how short-term debt is related to how firms manage their earnings. I use discretionary accruals and real operating decisions as the earnings management method.
\end{abstract}

The study finds that debt in current liabilities only has a statistically significant impact on accrual earnings management, and short-term borrowings are only shown to have a statistically significant impact on real earnings management. These results indicate that managers engage in accrual earnings management of debt included in current liabilities and use real earnings management of short-term borrowings from financial institutions.

Therefore, this evidence indicates that managers engage in accrual earnings management of debt in included current liabilities when they face the liquidity risk of short-term debt, and the firms with debt financing constraints are likely to manage real earnings in spite of enhanced firm monitoring by lenders such as financial institutions. The findings in this study may have implications in the debate about the monitoring function of financial institutions such as banks.

Keywords: Short-Term Debt, Accrual Earnings Management, Real Earnings Management

\section{INTRODUCTION}

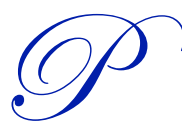

rior studies suggest that when firms raise funds through debt financing, the firms should consider not only the debt ratio but also the type of debt, maturity, collateral, and covenants. In firms with high liabilities, there is increased attention on earnings and risk according to the debt maturity structure. Long-term debt causes ineffective management of funds, owing to the existence of surplus cash; however, in the case of short-term debt, because the debt maturity is short and the frequency of new loans increases, maturity extension costs will be charged or liquidity risk will emerge, making conversion difficult. When debt ratio is considered to carry a serious risk of default, there should be more focus on the liquidity of short-term debt than the ineffective management of long-term debt.

To avoid liquidity risk, there are some corporations that maintain debt maturity by improving financial strength (Stulz, 1990), but there are other corporations that try to increase earnings to meet the terms of loans (Gupta and Fields, 2006). In particular, if a company carefully considers liquidity risk, they will be more able to manage earnings. Gupta and Fields (2006) show that the shorter the debt, the more earnings management. In addition, in the case of a low credit level, there is an enhanced relation between earnings management and short-term debt, and auditor characteristics diminish this relation.

However, lenders such as financial institutions have characteristics such as low asymmetry of information, high intelligence analysis capabilities, and lower transaction costs related to investment in companies (Diamond, 1984; Fama, 1985; Bhattacharya and Chiesa, 1995; Bharath et al., 2008). Thus, if managers are manipulating earnings, 
lenders such as banks will be more likely to monitor them. This can discourage managers from misbehaving (Gertner et al., 1994; Chemmanur and Fulghieri, 1994).

Although earnings management appears during short-term debt in the U.S. market where the debt contract is stricter, there have been no previous studies considering short-term debt to financial institutions. In Korea, debt to financial institutions does not affect accrual-based earnings management (Kim and Park, 2014). Therefore, this study investigates whether or not earnings management appears during short-term debt, with a particular focus on debt to financial institutions and debt in current liabilities. In addition, this study examines whether firms use discretionary accruals or real operating decisions to manage earnings. I use discretionary accruals as a proxy for accrual-based earnings management, and use abnormal cash flows from operations, abnormal production costs, and abnormal discretionary expenses as proxies for real earnings management.

This paper is organized as follows. I review prior literature and develop hypotheses in section 2. Section 3 describes data selection and empirical method. Empirical results are presented and discussed in section 4, and I conclude in section 5 .

\section{LITERATURE REVIEW AND HYPOTHESES}

Earnings management is related to earnings adjustment and focused on a particular debt covenant theory (Gupta and Fields, 2006). According to general debt contract theory, when debt ratio is high, a company increases net income through accounting choices. Previous research within the U.S. has generally confirmed the validity of the contract theory.

In their Korea study, Park et al. (2006) found that when debt ratio becomes high, capital is financed outside the company. To decrease this cost, the company intentionally raises the earnings level. Park (2001) shows that a company with a high debt ratio, even if it does not have a debt contract, is likely to adjust earnings to decrease the cost of debt capital and to make it easy to receive additional capital financing. However, some cases show companies trying to adjust earnings downward when debt ratio increases (Healy and Palepu, 1990; Beneish and Press, 1993; DeAngelo et al., 1994; Becker et al., 1998; Ashbaugh et al., 2003).

According to the covenant-based hypothesis, a company is highly likely to violate a particular debt covenant. Therefore, it tries to conduct an accounting choice to increase net income or to draw future profit. In accordance with this hypothesis, DeFond and Jiambalvo (1994) show that companies violating the covenant conduct an earnings adjustment to increase reported earnings during the current and prior year. In contrast, Sweeney (1994) finds that companies conduct accounting choices to increase reported earnings after the violation of the debt covenant. The empirical evidence is inconclusive. However, both studies agree that a company likely to violate a debt covenant raises earnings to decrease the possibility of violating the debt covenant and will conduct accounting choices to increase cash flow.

The possibility of violating a particular debt covenant is related to the character of the debt. Paek and Choi (1999) report that companies that are expected to owe high corporate taxes report more adjustments to decrease accounting earnings as compared to companies without high corporate taxes. This indicates that the effort to minimize corporate tax precedes earnings adjustments motivated by the increase of debt ratio. Moon (2007) finds that companies with a higher debt ratio report more earnings changes and the discretionary accounting choice factor of their CEOs is not strong.

Reported earnings are generally regarded as an important factor in appraisals of a firm's risk. Short-term debt increases a firm's liquidity risk. If the liquidity risk of short-term debt is higher than the burden of long-term debt, the firm needs to conduct earnings manipulation. The decision whether to conduct earnings management depends on the situation of the firm. Ahn (2004) suggests that lenders to a company that has a higher debt ratio monitor the company's activities and watch the CEO for earnings management. 
When the risk of the total debt contract is high, the company manipulates earnings upward. This relation is significantly stronger for firms that have much more short-term debt (Gupta and Fields, 2006). Fung and Goodwin (2013) report that short-term debt is positively associated with accrual-based earnings management and this relation is significantly weaker for firms that are of higher creditworthiness.

Managers achieve real activities manipulation by altering the level or the nature of economic activities and achieve accrual-based earnings management by choosing accounting policies and estimating accruals (DeFond and Jiambalvo, 1994; Fung and Goodwin, 2013). Managers have used accrual-based and real-based earnings management complementarily. Therefore, this study expects that short-term debt is related to accrual-based earnings management and real-based earnings management. The hypotheses are the following:

Hypothesis 1: There is a positive relation between total current liabilities and accrual-based earnings management.

Hypothesis 2: There is a positive relation between total current liabilities and real-based earnings management.

Financial institutions provide most external debt financing for firms. With repeated contracting with borrowers, financial institutions continuously gather information and update their evaluations of firm creditworthiness. Myers et al. (2003) suggest that a firm has to approach lenders more often to obtain new loans when debt maturity is short. More frequent evaluations are likely to serve as a monitoring tool. Monitoring by lenders of short-term debt of firms with low liquidity risk can increase accounting quality. The relationship between debt to financial institutions and earnings management is not clear. Therefore, this study uses debt in current liabilities and debt to financial institutions as the proxies of short-term debt for investigating this relationship. In addition, it develops the below sub-hypotheses for examining which type of earnings management is used.

Sub-hypothesis 1-1: There is a positive relation between debt in current liabilities and accrual-based earnings management.

Sub-hypothesis 1-2: There is a positive relation between short-term borrowings and accrual-based earnings management.

Sub-hypothesis 2-1: There is a positive relation between debt in current liabilities and real-based earnings management.

Sub-hypothesis 2-2: There is a positive relation between short-term borrowings and real-based earnings management.

\section{RESEARCH DESIGN}

\section{Research Methods}

This study uses the following regression model to find out the association between short-term debt—in particular, short-term debt to financial institutions and debt included in current liabilities - and earnings management. The absolute value of discretionary accruals is used as the dependent variable. Following Dechow et al. (1995) and Kothari et al. (2005), this study measures the magnitude of discretionary accruals. The independent variables are total current liabilities, debt included in current liabilities, and short-term borrowings as proxies for short-term debt. Total current liabilities (TCLi,t) represents liabilities due within one year, including the current portion of long-term debt. Debt included in current liabilities (DCLi,t) represents the total amount of short-term notes and the current portion of long-term debt (debt due in one year). Short-term borrowings (STBi,t) are the average of short-term borrowings and are usually in the form of lines of credit with banks. The other variables are control variables. LEVi,t is the total leverage of a firm; CFOi,t is the operating activities net cash flow; SIZEi,t is firm size; MTBi,t is growth opportunity; $\mathrm{ROA}_{\mathrm{i}, \mathrm{t}+1}$, is firm performance; Big $5 \mathrm{i}, \mathrm{t}$ is a Big 5 audit firm; and $\log \mathrm{TA} \mathrm{i}, \mathrm{t}-1$ is total accruals in the last year. LOSSi,t represents firms reporting losses for three consecutive years, and AUDCHi,t is changes in the auditing firm. The model is also controlled by years and group of industry: 


$$
/ D A_{i, t} /=0_{1}{ }_{1} S T D_{i, t}+{ }_{2} \text { CONTROL }+{ }_{i, t}
$$

Next, this study examines the relation between real earnings management and short-term debt by estimating the following regressions:

$$
\begin{aligned}
& \text { REM } M_{i, t}={ }_{0}+{ }_{1} S T D_{i, t}+{ }_{2} \text { CONTROL }+{ }_{i, t} \\
& \text { CREM }_{i, t}={ }_{0}+{ }_{1} S T D_{i, t}+{ }_{2} \text { CONTROL }+{ }_{i, t}
\end{aligned}
$$

Where REMi,t is abnormal CFO, abnormal production costs, or abnormal discretionary expenses. The abnormal CFO is expected to be significantly negative, abnormal production costs to be significantly positive and abnormal discretionary expenses to be significantly negative. In addition, I calculate a single variable by combining these individual variables, and the combined variable (CREMi,t) is computed as the sum of the standardized variables. This study uses these four variables as proxies for real earnings management. Control variables are the same as equation (1).

\section{Research Variables}

\section{Accrual-Based Earnings Management and Real Earnings Management}

Following Dechow et al. (1995), I measure the magnitude of discretionary accruals to estimate accrual earnings management. I run the following regression model for every industry and each year to estimate the $\alpha_{1}$ and $\alpha_{2}$ coefficients:

$$
\frac{T A_{i, t}}{A_{i, t}}={ }_{0}+{ }_{1}\left(\frac{1}{A_{i, t}}\right)+{ }_{2}\left(\frac{R E V_{l, t} \quad R E C_{i, t}}{A_{i, t}}\right)+{ }_{3}\left(\frac{P P E_{i, t}}{A_{i, t 1}}\right)+{ }_{i, t}
$$

Where $\mathrm{TA}_{\mathrm{i}, t}$ is total accruals in year $\mathrm{t}$ for firm $\mathrm{i} ; \mathrm{A}_{\mathrm{i}, \mathrm{t}-1}$ is total assets in year $\mathrm{t}-1$ for firm $\mathrm{i} ; \Delta \mathrm{REV}_{\mathrm{i}, \mathrm{t}}$ is the change in sales from year $\mathrm{t}-1$ to year $\mathrm{t}$ for firm $\mathrm{i} ; \Delta \mathrm{REC}_{\mathrm{i}, \mathrm{t}}$ is the change in accounts receivable from year $\mathrm{t}-1$ to year $\mathrm{t}$ for firm $\mathrm{i}$; $\mathrm{PPE}_{\mathrm{i}, \mathrm{t}}$ is total gross of property, plant and equipment in year t for firm $\mathrm{i}$; and $\epsilon_{i, t}$ is the error term in year $\mathrm{t}$ for firm i. In particular, total accruals are net income minus cash flow from operations.

Following Kothari et al. (2005), I run the following regression model for every industry and year to estimate the $\alpha_{1}$ and $\alpha_{2}$ coefficients:

$$
\frac{T A_{i, t}}{A_{i, t-1}}=\alpha_{0}+\alpha_{1}\left(\frac{1}{A_{i, t-1}}\right)+\alpha_{2}\left(\frac{\Delta R E V_{I, t}-\Delta R E C_{i, t}}{A_{i, t-1}}\right)+\alpha_{3}\left(\frac{P P E_{i, t}}{A_{i, t-1}}\right)+\alpha_{4}\left(\frac{R O A_{i, t}}{A_{i, t-1}}\right)+\varepsilon_{i, t}
$$

I calculate non-discretionary accruals as the estimated value from equation (4) and (5), and obtain the absolute value of discretionary accruals as equation (8):

$$
\begin{aligned}
& M J N A_{i, t}=\hat{\alpha}_{1}\left(\frac{1}{A_{i, t-1}}\right)+\hat{\alpha}_{2}\left(\frac{\Delta R E V_{I, t}-\Delta R E C_{i, t}}{A_{i, t-1}}\right)+\hat{\alpha}_{3}\left(\frac{P P E_{i, t}}{A_{i, t-1}}\right) \\
& K W N A_{i, t}=\hat{\alpha}_{1}\left(\frac{1}{A_{i, t-1}}\right)+\hat{\alpha}_{2}\left(\frac{\Delta R E V_{I, t}-\Delta R E C_{i, t}}{A_{i, t-1}}\right)+\hat{\alpha}_{3}\left(\frac{P P E_{i, t}}{A_{i, t-1}}\right)+\hat{\alpha}_{4}\left(\frac{R O A_{i, t}}{A_{i, t-1}}\right)
\end{aligned}
$$




$$
\begin{aligned}
& / \mathrm{DAMJ} /=/ \frac{T A_{i, t}}{A_{i, t 1}} \quad M J N A_{i, t} / \\
& / \mathrm{DAKW} /=/ \frac{T A_{i, t}}{A_{i, t+1}} \quad K W N A_{i, t} /
\end{aligned}
$$

Next, following Dechow et al. (1995) and Roychowdhury (2006), this study uses abnormal cash flows from operations, abnormal production costs, and abnormal discretionary expenses as the proxies for real earnings management. To estimate the models, I run the following regressions for every industry and each year:

$$
\begin{aligned}
& \frac{C F O_{t}}{A_{t 1}}={ }_{0}+{ }_{1}\left(\frac{1}{A_{t 1}}\right)+{ }_{2}\left(\frac{S_{t}}{A_{t}}\right)+{ }_{3}\left(\frac{S_{t 1}}{A_{t}}\right)+{ }_{t} \\
& \frac{P R O D_{t}}{A_{t 1}}={ }_{0}+{ }_{1}\left(\frac{1}{A_{t 1}}\right)+{ }_{2}\left(\frac{S_{t}}{A_{t}}\right)+{ }_{3}\left(\frac{S_{t}}{A_{t}}\right)+{ }_{4}\left(\frac{S_{t}}{A_{t 1}}\right)+{ }_{t} \\
& \frac{D \text { ISEXP }}{A_{t}}={ }_{0}+{ }_{1}\left(\frac{1}{A_{t}}\right)+{ }_{2}\left(\frac{S_{t 1}}{A_{t}}\right)+{ }_{t}
\end{aligned}
$$

Where $\mathrm{CFO}_{\mathrm{t}}$ are cash flows from operations in year $\mathrm{t} ; \mathrm{A}_{\mathrm{t}-1}$ is total assets in year $\mathrm{t}-1 ; \mathrm{S}_{\mathrm{t}}$ is sales revenues in year $\mathrm{t}$; and $\Delta \mathrm{S}_{\mathrm{t}}$ is the change in sales revenues from year $\mathrm{t}-1$ to year t. Production costs $\left(\mathrm{PROD}_{\mathrm{t}}\right)$ are computed as the cost of goods sold plus change in inventories from year $t-1$ to year $t$; and discretionary expenses (DISEXP $t_{t}$ ) are computed as selling, general and administrative expenses (SG\&A) plus advertising expenses plus research and development expenses (R\&D).

Abnormal value is the actual value minus the normal value for each firm year. I calculate normal value using estimated coefficients. Abnormal cash flows from operations (ABCFO) are the actual cash flows from operations minus the normal cash flows from operations; abnormal production costs (ABPRO) are the actual discretionary expenses minus the normal production costs; and abnormal discretionary expenses (ABDISEXP) are the actual discretionary expenses minus the normal discretionary expenses. Also, a combined variable $\left(\mathrm{CREM}_{\mathrm{i}, \mathrm{t}}\right)$ is computed as the sum of the standardized variables. Consistent with Zang (2006) and Cohen and Zarowin (2008), I multiply abnormal CFO and abnormal discretionary expenses by -1 . Therefore, the higher the amount of two variables, the more likely it is that the firm is engaging in earnings management.

$$
\text { CREM }_{i, t}=A B C F O \cdot(1)+A B P R O D+A B D I S E P \cdot(1)
$$

\section{Control Variables}

Control variables are included based on the findings of prior studies. Leverage ratio potentially affects firm performance and debt possession (DeFond and Jiambalvo, 1994). The leverage ratio denoted as LEV is measured with debt/asset to control for any potential impacts. Management tends to increase earnings if operating activities net cash flow is negative (Park, 2003). Therefore, this study uses the ratio of operating activities net cash flow to total assets in year $\mathrm{t}-1$, denoted as CFO as a control variable. The larger the firm, the more likely it is to be a political target. So management tends to decrease the accounting performance to decrease the political cost (Watts and Zimmerman, 1990). Therefore, this study uses the natural log of total assets denoted as SIZE to control for firm size.

Firms with higher growth opportunities increase their earnings according to the estimated profit of analysts to protect the expropriation of minority shareholders (Yoon, 2001; Skinner and Sloan, 2002). This study uses the ratio of the book value to market value, denoted as MTB, to control for growth opportunity. DeFond and Park (1997) report that future financial performance is positively associated with the amount of accruals. Therefore, I include future financial performance as a control variable. This study uses the ratio of income before extraordinary items in year $\mathrm{t}+1$ to total assets in year $\mathrm{t}-1$, denoted as FNI (DeFond and Subramanyam, 1998). This study includes the total accruals of the previous term to control for the reversal phenomenon of earnings management (Ashbaugh et al., 
2003; Becker et al., 1998). lagTA is measured by the ratio of net income minus operating activities net cash flow in year $\mathrm{t}-1$ to total assets in year $\mathrm{t}-2$.

Becker et al. (1998) insists that Big 4 auditors raise the quality of audits more than those from non-Big 4 firms. Firms audited by Big 4, 5, and 6 auditors are related to lower levels of discretionary accruals. Therefore, I include the Big 5 to control for this factor. Big 5 is 1 if the firm is audited by Arthur Andersen, Deloitte \& Touche, Ernst \& Young, KPMG, Price Waterhouse, Coopers and Lybrand or PricewaterhouseCoopers, and 0 for others. In addition, short auditor tenure leads to high asymmetry of information (Mansi et al., 2006). Therefore, AUDCH is 1 if the auditor is changed and otherwise 0. LOSS is proxy for risk firms, which are more likely to manage earnings. Therefore, I include LOSS to control for this effect. LOSS is 1 if the firm reports a loss during three consecutive years and 0 otherwise. This study also controls by years and groups of industry.

\section{RESEARCH RESULT}

\section{Sample Selection}

The initial sample consists of all U.S. non-financial industries from Compustat between 2004 and 2011. Firms in the transportation and public utilities industries (SIC codes 40-49) and in finance are excluded, as well as those in the insurance and real estate industries (SIC 60-67). As long as SG\&A is available, advertising expenses and R\&D are set to zero if this data concerning them is missing. Available data is included to calculate variables for each firmyear. The accrual models and the models for normal and expected CFO, discretionary expenses, and production costs are estimated for each year and industry. There are at least 8 observations for each industry-year grouping. Final samples consist of 1,146 firm-year observations.

\section{Descriptive Statistics}

Table 1 reports descriptive statistics for the variables used in the study. All variables are winsorized at the $1 \%$ level to reduce the influence of outliers. Absolute discretionary accruals (/DAMJ/) are $11.1 \%$ of firms' assets, total current liabilities $14.7 \%$, debt included in current liabilities $0.4 \%$, and short-term borrowings $0.1 \%$. /DAMJ/ mean of $11.1 \%$, /DAKW/ mean of $9.9 \%$ and REM mean of $0.3 \%$ suggest that firms are engaging in earnings management. Total liabilities of firms' assets are $22.0 \%$, and $65.0 \%$ of the firms are audited by one of the Big 5 auditors.

Table 1. Descriptive Statistics $(\mathrm{N}=1,466)$

\begin{tabular}{|c|c|c|c|c|c|c|c|}
\hline & \multirow{2}{*}{ Min } & \multirow{2}{*}{$\operatorname{Max}$} & \multirow{2}{*}{ Mean } & \multicolumn{3}{|c|}{ Quartile } & \multirow{2}{*}{$\begin{array}{l}\text { Standard } \\
\text { Deviation }\end{array}$} \\
\hline & & & & $25 \%$ & $50 \%$ & $75 \%$ & \\
\hline DAMJ & -0.748 & 0.390 & 0.004 & -0.054 & 0.021 & 0.084 & 0.167 \\
\hline$|\mathrm{DAMJ}|$ & 0.000 & 0.748 & 0.111 & 0.033 & 0.071 & 0.136 & 0.125 \\
\hline DAKW & -0.603 & 0.437 & -0.004 & -0.066 & 0.000 & 0.060 & 0.149 \\
\hline$|\mathrm{DAKW}|$ & 0.000 & 0.603 & 0.099 & 0.023 & 0.063 & 0.135 & 0.112 \\
\hline -ABCFO & -1.102 & 1.312 & -0.014 & -0.125 & -0.030 & 0.074 & 0.297 \\
\hline ABPROD & -0.393 & 0.452 & -0.001 & -0.058 & -0.010 & 0.048 & 0.130 \\
\hline -ABDISEXP & -2.575 & 1.426 & 0.019 & -0.085 & 0.062 & 0.220 & 0.518 \\
\hline REM & -1.998 & 1.046 & 0.003 & -0.124 & 0.022 & 0.214 & 0.440 \\
\hline LCT & 0.004 & 0.661 & 0.147 & 0.047 & 0.102 & 0.203 & 0.140 \\
\hline DLC & 0.000 & 0.230 & 0.004 & 0.000 & 0.000 & 0.000 & 0.020 \\
\hline STB & 0.000 & 0.129 & 0.001 & 0.000 & 0.000 & 0.000 & 0.006 \\
\hline LEV & 0.010 & 0.828 & 0.220 & 0.078 & 0.163 & 0.322 & 0.185 \\
\hline SIZE & 0.542 & 8.856 & 4.372 & 2.998 & 4.398 & 5.518 & 1.864 \\
\hline MTB & 0.242 & 38.476 & 3.888 & 1.313 & 2.458 & 4.418 & 5.206 \\
\hline $\mathrm{ROA}_{\mathrm{t}+1}$ & -1.942 & 0.469 & -0.145 & -0.227 & -0.046 & 0.074 & 0.398 \\
\hline $\operatorname{lagTA_{t+1}}$ & -4.531 & 0.477 & -0.172 & -0.148 & -0.065 & -0.013 & 0.563 \\
\hline BIG6 & 0.000 & 1.000 & 0.650 & 0.000 & 1.000 & 1.000 & 0.477 \\
\hline $\mathrm{CFO} / \mathrm{ASSET}_{\mathrm{t}-1}$ & -1.826 & 0.675 & -0.061 & -0.141 & -0.017 & 0.156 & 0.383 \\
\hline LOSS & 0.000 & 1.000 & 0.584 & 0.000 & 1.000 & 1.000 & 0.493 \\
\hline AUDCH & 0.000 & 1.000 & 0.090 & 0.000 & 0.000 & 0.000 & 0.286 \\
\hline
\end{tabular}

$※$ See research model to identify operational definition of variable 
Table 2 presents correlations between variables. /DAMJ/ and /DAKW/ are positively related to measurement of debt included in current liabilities. This is probably because managers engage in accrual earnings management. MTB and LOSS are positively related to absolute discretionary accruals. SIZE, ROA, TA, BIG5, and CFO are negatively correlated with absolute discretionary accruals. Absolute discretionary accruals are correlated with most of the control variables.

Table 2. Pearson Correlation $(\mathrm{N}=1,466)$

\begin{tabular}{|c|c|c|c|c|c|c|c|c|c|c|}
\hline & DAMJ & |DAMJ| & DAKW & |DAKW $\mid$ & -AB CFO & $\begin{array}{l}\text { ABP } \\
\text { ROD }\end{array}$ & $\begin{array}{l}\text {-ABDI } \\
\text { SEXP }\end{array}$ & REM & LCT & DLC \\
\hline DAMJ & 1.000 & & & & & & & & & \\
\hline$|\mathrm{DAMJ}|$ & $-0.366^{* * *}$ & 1.000 & & & & & & & & \\
\hline DAKW & $0.902^{* * *}$ & $-0.243^{* * *}$ & 1.000 & & & & & & & \\
\hline$|\mathrm{DAKW}|$ & $-0.290^{* * *}$ & $0.853^{* * *}$ & $-0.151^{* * *}$ & 1.000 & & & & & & \\
\hline -ABCFO & $-0.204^{* * *}$ & $0.151^{* * *}$ & -0.031 & $0.170^{* * *}$ & 1.000 & & & & & \\
\hline ABP ROD & $-0.142^{* * *}$ & $0.141^{* * *}$ & $-0.078^{* * *}$ & $0.108^{* * *}$ & $0.116^{* * *}$ & 1.000 & & & & \\
\hline -ABDI SEXP & $0.342^{* * *}$ & $-0.233^{* * *}$ & $0.208^{* * *}$ & $-0.228^{* * *}$ & $-0.754^{* * *}$ & $0.190^{* * *}$ & 1.000 & & & \\
\hline REM & $0.232^{* * *}$ & $-0.139^{* * *}$ & $0.205^{* * *}$ & $-0.130^{* * *}$ & $-0.232^{* * *}$ & $0.624^{* * *}$ & $0.773^{* * *}$ & 1.000 & & \\
\hline LCT & $-0.066^{* *}$ & 0.020 & -0.044 & 0.040 & $0.145^{* * *}$ & $0.073^{* *}$ & $-0.150^{* * *}$ & $-0.067^{* *}$ & 1.000 & \\
\hline DLC & $-0.064^{* *}$ & $0.117^{* * *}$ & $-0.057^{*}$ & $0.106^{* * *}$ & $0.092^{* * *}$ & 0.009 & $-0.085^{* * *}$ & $-0.050^{*}$ & $0.173^{* * *}$ & 1.000 \\
\hline STB & $0.066^{* *}$ & 0.017 & $0.056^{*}$ & 0.009 & $-0.080^{* * *}$ & 0.019 & $0.107^{* * *}$ & $0.076^{* * *}$ & $0.121^{* * *}$ & $0.218^{* * *}$ \\
\hline LEV & -0.041 & 0.012 & -0.036 & 0.023 & $0.106 * * *$ & 0.036 & $-0.116 * * *$ & $-0.062 * *$ & $0.740_{* * *}$ & $0.178_{* * *}$ \\
\hline SIZE & $0.068^{* *}$ & $-0.212^{* * *}$ & $-0.075^{* *}$ & $-0.219^{* * *}$ & $-0.187^{* * *}$ & $-0.061^{* *}$ & $0.142^{* * *}$ & 0.033 & -0.042 & 0.026 \\
\hline MTB & $-0.127^{* * *}$ & $0.130^{* * *}$ & $-0.064^{* *}$ & $0.157^{* * *}$ & $0.248^{* * *}$ & -0.044 & $-0.360^{* * *}$ & $-0.283^{* * *}$ & $0.312^{* * *}$ & $0.072^{* *}$ \\
\hline $\mathrm{ROA}_{\mathrm{t}+1}$ & $0.208^{* * *}$ & $-.215^{* * *}$ & -0.005 & $-0.237^{* * *}$ & $-0.405^{* * *}$ & $-0.066^{* *}$ & $0.322^{* * *}$ & $0.107^{* * *}$ & -0.025 & -0.047 \\
\hline $\operatorname{lagTA_{t-1}}$ & $0.172^{* * *}$ & $-0.194^{* * *}$ & $0.086^{* * *}$ & $-0.171^{* * *}$ & $-0.165^{* * *}$ & -0.033 & $0.178^{* * *}$ & $0.092^{* * *}$ & -0.026 & -0.027 \\
\hline BIG6 & 0.011 & $-0.105^{* * *}$ & -0.023 & $-0.098^{* * *}$ & -0.043 & -0.058 & 0.020 & -0.017 & 0.037 & -0.011 \\
\hline $\mathrm{CFO} /$ Asset $_{\mathrm{t}-1}$ & $0.166^{* * *}$ & $-0.294^{* * *}$ & $-0.099^{* * *}$ & $-0.310^{* * *}$ & $-0.624^{* * *}$ & $-0.094^{* * *}$ & $0.469^{* * *}$ & $0.145^{* * *}$ & 0.025 & $-0.113^{* * *}$ \\
\hline LOSS & $-0.223^{* * *}$ & $0.138^{* * *}$ & $-0.065^{* *}$ & $0.146^{* * *}$ & $0.230^{* * *}$ & $0.143^{* * *}$ & $-0.118^{* * *}$ & $0.055^{*}$ & $-0.121^{* * *}$ & 0.038 \\
\hline AUDCH & 0.017 & 0.044 & 0.028 & $0.051^{*}$ & -0.002 & 0.022 & 0.001 & 0.019 & $0.056^{*}$ & 0.044 \\
\hline
\end{tabular}

(Table 2 continued)

\begin{tabular}{|c|c|c|c|c|c|c|c|c|c|c|}
\hline & STB & LEV & SIZE & МТВ & $\mathbf{R O A}_{t+1}$ & $\operatorname{lag} T A_{t-1}$ & BIG6 & $\begin{array}{c}\text { CFO/ } \\
\text { Asset }_{\text {t-1 }} \\
\end{array}$ & LOSS & AUDCH \\
\hline STB & 1.000 & & & & & & & & & \\
\hline LEV & $0.068^{* *}$ & 1.000 & & & & & & & & \\
\hline SIZE & 0.012 & $0.227^{* * *}$ & 1.000 & & & & & & & \\
\hline MTB & -0.031 & $0.263^{* * *}$ & $-0.130^{* * *}$ & 1.000 & & & & & & \\
\hline $\mathrm{ROA}_{\mathrm{t}+1}$ & 0.043 & 0.043 & $0.444^{* * *}$ & $-0.150^{* * *}$ & 1.000 & & & & & \\
\hline $\operatorname{lagTA_{t-1}}$ & 0.035 & -0.048 & $0.107^{* * *}$ & $-0.101^{* * *}$ & $0.240^{* * *}$ & 1.000 & & & & \\
\hline BIG6 & $-0.079^{* * *}$ & $0.168^{* * *}$ & $0.495^{* * *}$ & $-0.072^{* *}$ & $0.183^{* * *}$ & $0.072^{* *}$ & 1.000 & & & \\
\hline $\mathrm{CFO}$ Asset $_{\mathrm{t}-1}$ & 0.011 & $0.092^{* * *}$ & $0.459^{* * *}$ & $-0.180^{* * *}$ & $0.720^{* * *}$ & $0.268^{* * *}$ & $0.223^{* * *}$ & 1.000 & & \\
\hline LOSS & -0.031 & $-0.170^{* * *}$ & $-0.459^{* * *}$ & 0.007 & $-0.485^{* * *}$ & $-0.126^{* * *}$ & $-0.178^{* * *}$ & $-0.556^{* * *}$ & 1.000 & \\
\hline AUDCH & -0.026 & 0.028 & $-0.090^{* * *}$ & 0.007 & -0.035 & $-0.062^{* *}$ & $-0.121^{* * *}$ & $-0.049^{*}$ & 0.043 & 1.000 \\
\hline
\end{tabular}

This suggests that this study controls for variables identified as significant factors for phenomenon of earnings management (Fung and Goodwin, 2013). 
REM is negatively related to measurement of total current liabilities at $5 \%$ and is positively correlated with shortterm borrowings at a $1 \%$ level. This is probably because managers engage in real earnings management. LEV and MTB are negatively correlated with REM, and ROA, TA, and CFO are positively related to REM. Short-term debt is positively or negatively correlated with the real-based earnings management variables.

\section{Multivariate Analysis}

Table 3 reports results of multivariate regressions for accrual earnings management and real earnings management. Columns (1) through (3) present results of regressions for accrual earnings management. Following Dechow et al. (1995), this study measures the magnitude of discretionary accruals. Columns (4) through (6) present results of regressions for accrual earnings management. Following Kothari et al. (2005), performance-matched discretionary accruals are used. Columns (7) through (9) report results for real earnings management.

Hypotheses 1 and 2 predict that the coefficient of total current liabilities should be positive. The coefficients of total current liabilities are statistically positive or negative but insignificant. The results of this regression indicate that total current liabilities do not have impact on accrual or real earnings management.

Sub-hypotheses 1-1 and 2-1 predict that the coefficient of debt included in current liabilities should be positive. Columns (2), (5) and (8) in Table 4 provide the results. Debt included in current liabilities only has a statistically significant impact on /DAMJ/ and /DAKW/. These results suggest that firms are likely to manage accrual earnings when they face the liquidity risk of short-term debt.

A similar relation between earnings management by /DAMJ/ and /DAKW/ and control variables is observed when debt included in current liabilities is used as the current debt proxies. Regarding the control variables, the significant coefficients are found to be generally in the expected directions. The signs of the coefficients on the SIZE, TA, CFO and LOSS are negative and significant.

Sub-hypotheses 1-2 and 2-2 predict that the coefficient of short-term borrowings should be positive. However, shortterm borrowings are only shown to have a statistically significant impact on REM. These results indicate that the higher the short-term borrowings, the more real earnings management. Financial institutions are more concerned with monitoring financial statements to continuously gather information and update their evaluations of firm creditworthiness. There is also expected legal liability costs related to accrual earnings management, which causes firms to be more likely to manipulate real activities (Cohen et al., 2008). The coefficients of CFO and LOSS are positive and significant, and those of MTM and BIG5 are negative and significant.

Abnormal CFO, abnormal production costs, and abnormal discretionary expenses are the proxies for real earnings management, and are the dependent variables in Table 4. When the dependent variable in regressions is abnormal $\mathrm{CFO}$, the coefficient on short-term borrowings is negative and significant at a $1 \%$ level. These results indicate that there is certain real earnings management such as increasing price discounts and facilitating credit sales. When the dependent variable in regressions is abnormal production costs, the coefficient of total current liabilities is positive and significant at a $10 \%$ level. These results indicate that firms may engage in earnings management through overproduction and increased inventory to report lower cost of goods sold. Finally, when the dependent variable in regressions is abnormal discretionary expenses, the coefficient of short-term borrowings is positive and significant at a $1 \%$ level. These results indicate that firms may engage in earnings management through decreasing $\mathrm{R} \& \mathrm{D}$, advertising expenses, and SG\&A to report lower discretionary spending. 
Table 3. The Effect of Short-term Debt on Earnings Management $(\mathrm{N}=1,466)$

Panel A

\begin{tabular}{|c|c|c|c|c|c|c|}
\hline & \multicolumn{6}{|c|}{ Dependent Variable: |DAMJ| } \\
\hline & \multicolumn{2}{|c|}{ Model 1} & \multicolumn{2}{|c|}{ Model 2} & \multicolumn{2}{|c|}{ Model 3} \\
\hline & $\boldsymbol{\beta}$ & t-stat & $\beta$ & t-stat & $\beta$ & t-stat \\
\hline LCT & 0.012 & 0.218 & & & & \\
\hline DLC & & & 0.076 & $2.651^{* * *}$ & & \\
\hline STB & & & & & 0.039 & 1.336 \\
\hline LEV & 0.025 & 0.493 & 0.016 & 0.492 & 0.028 & 0.880 \\
\hline SIZE & -0.117 & $-2.870^{* * *}$ & -0.124 & $-3.226^{* * *}$ & -0.120 & $-3.116^{* * *}$ \\
\hline MTB & 0.065 & 2.113 & 0.065 & $2.118^{* *}$ & 0.068 & $2.214^{* *}$ \\
\hline $\mathrm{ROA}_{\mathrm{t}+1}$ & 0.022 & 0.529 & 0.019 & 0.443 & 0.019 & 0.445 \\
\hline $\operatorname{lagTA_{t+1}}$ & -0.114 & $-3.932^{* * *}$ & -0.115 & $-3.999^{* * *}$ & -0.115 & $-3.972^{* * *}$ \\
\hline BIG6 & 0.026 & 0.807 & 0.029 & 0.882 & 0.031 & 0.947 \\
\hline $\mathrm{CFO} / \mathrm{ASSET}_{\mathrm{t}-1}$ & -0.249 & $-5.606^{* * *}$ & -0.236 & $-5.286^{* * *}$ & -0.248 & $-5.593^{* * *}$ \\
\hline LOSS & -0.083 & $-2.267^{* *}$ & -0.082 & $-2.259^{* *}$ & -0.083 & $-2.268^{* *}$ \\
\hline AUDCH & 0.022 & 0.765 & 0.019 & 0.682 & 0.023 & 0.825 \\
\hline Year Dummy & Included & Included & Included & Included & Included & Included \\
\hline Industry Dummy & Included & Included & Included & Included & Included & Included \\
\hline MAXVIF & \multicolumn{2}{|c|}{4.083} & \multicolumn{2}{|c|}{2.657} & \multicolumn{2}{|c|}{2.624} \\
\hline $\mathrm{F}$ & \multicolumn{2}{|c|}{$7.822 * * *$} & \multicolumn{2}{|c|}{$8.129 * * *$} & \multicolumn{2}{|c|}{$7.898 * * *$} \\
\hline Adj. $R^{2}$ & \multicolumn{2}{|c|}{0.139} & \multicolumn{2}{|c|}{0.144} & \multicolumn{2}{|c|}{0.140} \\
\hline
\end{tabular}

$*_{*}^{*}, * * * *$ are significant at a $10 \%, 5 \%$, and $1 \%$ level, respectively. See research model to identify operational definition of variable

Panel B

\begin{tabular}{|c|c|c|c|c|c|c|}
\hline & \multicolumn{6}{|c|}{ Dependent Variable: |DAKW| } \\
\hline & \multicolumn{2}{|c|}{ Model 4} & \multicolumn{2}{|c|}{ Model 5} & \multicolumn{2}{|c|}{ Model 6} \\
\hline & $\beta$ & t-stat & $\beta$ & t-stat & $\beta$ & t-stat \\
\hline LCT & -0.001 & -0.009 & & & & \\
\hline DLC & & & 0.062 & $2.164 * *$ & & \\
\hline STB & & & & & 0.021 & 0.725 \\
\hline LEV & 0.044 & 0.883 & 0.030 & 0.914 & 0.041 & 1.275 \\
\hline SIZE & -0.122 & $-2.991 * * *$ & -0.126 & $-3.253 * * *$ & -0.122 & $-3.160 * * *$ \\
\hline MTB & 0.086 & $2.764 * * *$ & 0.085 & $2.755^{* * *}$ & 0.087 & $2.812 * * *$ \\
\hline $\mathrm{ROA}_{t+1}$ & 0.016 & 0.376 & 0.013 & 0.304 & 0.014 & 0.329 \\
\hline $\operatorname{lagTA_{t+1}}$ & -0.084 & $-2.894 * * *$ & -0.085 & $-2.946 * * *$ & -0.084 & $-2.915 * * *$ \\
\hline BIG6 & 0.026 & 0.800 & 0.028 & 0.859 & 0.029 & 0.872 \\
\hline $\mathrm{CFO} / \mathrm{ASSET}_{\mathrm{t}-1}$ & -0.244 & $-5.479 * * *$ & -0.233 & $-5.211 * * *$ & -0.243 & $-5.472 * * *$ \\
\hline LOSS & -0.070 & $-1.929 *$ & -0.070 & $-1.924 *$ & -0.070 & $-1.931 *$ \\
\hline AUDCH & 0.024 & 0.836 & 0.022 & 0.767 & 0.025 & 0.867 \\
\hline Year Dummy & Included & Included & Included & Included & Included & Included \\
\hline Industry Dummy & Included & Included & Included & Included & Included & Included \\
\hline MAXVIF & \multicolumn{2}{|c|}{4.083} & \multicolumn{2}{|c|}{2.657} & \multicolumn{2}{|c|}{2.624} \\
\hline $\mathrm{F}$ & \multicolumn{2}{|c|}{$7.755^{* * *}$} & \multicolumn{2}{|c|}{$7.961 * * *$} & \multicolumn{2}{|c|}{$7.778 * * *$} \\
\hline Adj. $\mathrm{R}^{2}$ & \multicolumn{2}{|c|}{0.137} & \multicolumn{2}{|c|}{0.141} & \multicolumn{2}{|c|}{0.138} \\
\hline
\end{tabular}

$\varkappa^{*}, * *, * *$ are significant at a $10 \%, 5 \%$, and $1 \%$ level, respectively. See research model to identify operational definition of variable

(Table 3, Panel C continues on next page.) 
(Table 3, Panel C continued)

Panel C

\begin{tabular}{|c|c|c|c|c|c|c|}
\hline & \multicolumn{6}{|c|}{ Dependent Variable: REM } \\
\hline & \multicolumn{2}{|c|}{ Model 7} & \multicolumn{2}{|c|}{ Model 8} & \multicolumn{2}{|c|}{ Model 9} \\
\hline & $\beta$ & t-stat & $\beta$ & t-stat & $\beta$ & t-stat \\
\hline LCT & -0.012 & -0.220 & & & & \\
\hline DLC & & & -0.019 & -0.636 & & \\
\hline STB & & & & & 0.063 & $2.146^{* *}$ \\
\hline LEV & 0.029 & 0.568 & 0.024 & 0.731 & 0.013 & 0.396 \\
\hline SIZE & 0.024 & 0.584 & 0.028 & 0.718 & 0.026 & 0.666 \\
\hline MTB & -0.279 & $-8.827 * * *$ & -0.279 & $-8.889 * * *$ & -0.276 & $-8.793 * * *$ \\
\hline $\mathrm{ROA}_{t+1}$ & 0.035 & $0.828 * * *$ & 0.036 & 0.848 & 0.030 & 0.691 \\
\hline $\operatorname{lag} \mathrm{TA}_{\mathrm{t}+1}$ & 0.037 & 1.255 & 0.037 & 1.268 & 0.035 & 1.192 \\
\hline BIG6 & -0.064 & $-1.928 *$ & -0.065 & $-1.947 *$ & -0.057 & $-1.694 *$ \\
\hline 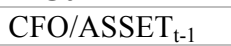 & 0.181 & $3.994 * * *$ & 0.178 & $3.895^{* * *}$ & 0.182 & $4.024 * * *$ \\
\hline LOSS & 0.191 & $5.145 * * *$ & 0.191 & $5.140 * * *$ & 0.191 & $5.147 * * *$ \\
\hline AUDCH & 0.010 & 0.343 & 0.010 & 0.363 & 0.013 & 0.439 \\
\hline Year Dummy & Included & Included & Included & Included & Included & Included \\
\hline Industry Dummy & Included & Included & Included & Included & Included & Included \\
\hline MAXVIF & \multicolumn{2}{|c|}{4.083} & \multicolumn{2}{|c|}{2.657} & \multicolumn{2}{|c|}{2.624} \\
\hline $\mathrm{F}$ & \multicolumn{2}{|c|}{$5.929 * * *$} & \multicolumn{2}{|c|}{$5.944 * * *$} & \multicolumn{2}{|c|}{$6.122 * * *$} \\
\hline Adj. $\mathrm{R}^{2}$ & \multicolumn{2}{|c|}{0.104} & \multicolumn{2}{|c|}{0.104} & \multicolumn{2}{|c|}{0.108} \\
\hline
\end{tabular}

$※ *, * *, * * *$ are significant at a $10 \%, 5 \%$, and $1 \%$ level, respectively. See research model to identify operational definition of variable.

Table 4. The Effect of Short-term Debt on Real Earnings Management $(\mathrm{N}=1,466)$

Panel A

\begin{tabular}{|c|c|c|c|c|c|c|}
\hline & \multicolumn{6}{|c|}{ Dependent Variable: -ABCFO } \\
\hline & \multicolumn{2}{|c|}{ Model 10} & \multicolumn{2}{|c|}{ Model 11} & \multicolumn{2}{|c|}{ Model 12} \\
\hline & $\beta$ & t-stat & $\boldsymbol{\beta}$ & t-stat & $\beta$ & t-stat \\
\hline LCT & 0.056 & 1.383 & & & & \\
\hline DLC & & & -0.008 & -0.400 & & \\
\hline STB & & & & & -0.060 & $-2.853 * * *$ \\
\hline LEV & 0.075 & $2.088 * *$ & 0.116 & $4.853 * * *$ & 0.121 & $5.152 * * *$ \\
\hline SIZE & -0.009 & -0.304 & -0.021 & -0.763 & -0.021 & -0.752 \\
\hline MTB & 0.093 & $4.128 * * *$ & 0.096 & $4.295 * * *$ & 0.093 & $4.154 * * *$ \\
\hline $\mathrm{ROA}_{\mathrm{t}+1}$ & 0.029 & 0.940 & 0.029 & 0.960 & 0.034 & 1.129 \\
\hline $\operatorname{lagTA_{t+1}}$ & 0.024 & 1.166 & 0.025 & 1.178 & 0.026 & 1.259 \\
\hline BIG6 & 0.049 & $2.079 * *$ & 0.049 & $2.076^{* *}$ & 0.042 & $1.778^{*}$ \\
\hline $\mathrm{CFO} / \mathrm{ASSET}_{\mathrm{t}-1}$ & -0.851 & $-26.417 * * *$ & -0.852 & $-26.257 * * *$ & -0.852 & $-26.505 * * *$ \\
\hline LOSS & -0.099 & $-3.724 * * *$ & -0.098 & $-3.694 * * *$ & -0.098 & $-3.699 * * *$ \\
\hline AUDCH & -0.019 & -0.930 & -0.019 & -0.912 & -0.022 & -1.055 \\
\hline Year Dummy & Included & Included & Included & Included & Included & Included \\
\hline Industry Dummy & Included & Included & Included & Included & Included & Included \\
\hline MAXVIF & \multicolumn{2}{|c|}{4.083} & \multicolumn{2}{|c|}{2.657} & \multicolumn{2}{|c|}{2.624} \\
\hline $\mathrm{F}$ & \multicolumn{2}{|c|}{$52.142 * * *$} & \multicolumn{2}{|c|}{$54.996 * * *$} & \multicolumn{2}{|c|}{$52.662 * * *$} \\
\hline Adj. $\mathrm{R}^{2}$ & \multicolumn{2}{|c|}{0.547} & \multicolumn{2}{|c|}{0.546} & \multicolumn{2}{|c|}{0.549} \\
\hline
\end{tabular}

$※ *, * *, * * *$ are significant at a $10 \%, 5 \%$, and $1 \%$ level, respectively. See research model to identify operational definition of variable.

(Table 4, Panel B and Panel C continues on next page) 
Panel B

(Table 4, Panel B and Panel C continued)

\begin{tabular}{|c|c|c|c|c|c|c|}
\hline & \multicolumn{6}{|c|}{ Dependent Variable: ABPRO } \\
\hline & \multicolumn{2}{|c|}{ Model 13} & \multicolumn{2}{|c|}{ Model 14} & \multicolumn{2}{|c|}{ Model 15} \\
\hline & $\beta$ & t-stat & $\boldsymbol{\beta}$ & t-stat & $\beta$ & t-stat \\
\hline LCT & 0.107 & $1.805^{*}$ & & & & \\
\hline DLC & & & -0.007 & -0.213 & & \\
\hline STB & & & & & 0.012 & 0.397 \\
\hline LEV & 0.014 & 0.266 & 0.089 & $2.537 * *$ & 0.086 & $2.489 * *$ \\
\hline SIZE & 0.030 & 0.698 & 0.006 & 0.142 & 0.005 & 0.128 \\
\hline MTB & -0.103 & $-3.112 * * *$ & -0.096 & $-2.935 * * *$ & -0.096 & $-2.914 * * *$ \\
\hline $\mathrm{ROA}_{\mathrm{t}+1}$ & 0.029 & 0.657 & 0.030 & 0.674 & 0.029 & 0.640 \\
\hline $\operatorname{lagTA_{t+1}}$ & -0.010 & -0.331 & -0.010 & -0.320 & -0.010 & -0.336 \\
\hline BIG6 & -0.064 & $-1.843 *$ & -0.064 & $-1.832 *$ & -0.062 & $-1.775^{*}$ \\
\hline CFO/ASSET $\mathrm{t}_{\mathrm{t}-1}$ & -0.075 & -1.592 & -0.075 & -1.582 & -0.074 & -1.564 \\
\hline LOSS & 0.166 & $4.282 * * *$ & 0.168 & $4.313 * * *$ & 0.168 & $4.313 * * *$ \\
\hline AUDCH & 0.002 & 0.077 & 0.003 & 0.088 & 0.003 & 0.099 \\
\hline Year Dummy & Included & Included & Included & Included & Included & Included \\
\hline Industry Dummy & Included & Included & Included & Included & Included & Included \\
\hline MAXVIF & \multicolumn{2}{|c|}{4.083} & \multicolumn{2}{|c|}{2.657} & \multicolumn{2}{|c|}{2.624} \\
\hline $\mathrm{F}$ & \multicolumn{2}{|c|}{$1.994 * * *$} & \multicolumn{2}{|c|}{$1.869^{* * *}$} & \multicolumn{2}{|c|}{$1.874 * * *$} \\
\hline Adj. $\mathrm{R}^{2}$ & \multicolumn{2}{|c|}{0.023} & \multicolumn{2}{|c|}{0.020} & \multicolumn{2}{|c|}{0.020} \\
\hline
\end{tabular}

$※ *, * *, * * *$ are significant at a $10 \%, 5 \%$, and $1 \%$ level, respectively. See research model to identify operational definition of variable.

Panel C

\begin{tabular}{|c|c|c|c|c|c|c|}
\hline & \multicolumn{6}{|c|}{ Dependent Variable: -ABDISEXP } \\
\hline & \multicolumn{2}{|c|}{ Model 16} & \multicolumn{2}{|c|}{ Model 17} & \multicolumn{2}{|c|}{ Model 18} \\
\hline & $\beta$ & t-stat & $\beta$ & t-stat & $\boldsymbol{\beta}$ & t-stat \\
\hline LCT & -0.057 & -1.217 & & & & \\
\hline DLC & & & -0.002 & -0.096 & & \\
\hline STB & & & & & 0.085 & $3.471 * * *$ \\
\hline LEV & -0.019 & -0.441 & -0.057 & $-2.063 * *$ & -0.068 & $-2.479 * *$ \\
\hline SIZE & 0.022 & 0.646 & 0.036 & 1.090 & 0.034 & 1.053 \\
\hline MTB & -0.264 & $-10.076^{* * *}$ & -0.268 & $-10.247 * * *$ & -0.263 & $-10.113 * * *$ \\
\hline $\mathrm{ROA}_{\mathrm{t}+1}$ & 0.016 & 0.447 & 0.016 & 0.443 & 0.008 & 0.222 \\
\hline $\operatorname{lagTA_{t+1}}$ & 0.029 & 1.170 & 0.029 & 1.167 & 0.026 & 1.068 \\
\hline BIG6 & -0.070 & $-2.533 * *$ & -0.070 & $-2.542 * *$ & -0.060 & $-2.169 * *$ \\
\hline $\mathrm{CFO} / \mathrm{ASSET}_{\mathrm{t}-1}$ & 0.598 & $15.886^{* * *}$ & 0.597 & $15.750 * * *$ & 0.599 & $15.985 * * *$ \\
\hline LOSS & 0.156 & $5.048 * * *$ & 0.155 & $5.020 * * *$ & 0.155 & $5.039 * * *$ \\
\hline AUDCH & 0.006 & 0.253 & 0.006 & 0.252 & 0.010 & 0.405 \\
\hline Year Dummy & Included & Included & Included & Included & Included & Included \\
\hline Industry Dummy & Included & Included & Included & Included & Included & Included \\
\hline MAXVIF & \multicolumn{2}{|c|}{4.083} & \multicolumn{2}{|c|}{2.657} & \multicolumn{2}{|c|}{2.624} \\
\hline $\mathrm{F}$ & \multicolumn{2}{|c|}{27.120} & \multicolumn{2}{|c|}{$27.029 * * *$} & \multicolumn{2}{|c|}{27.766} \\
\hline Adj. $R^{2}$ & \multicolumn{2}{|c|}{0.381} & \multicolumn{2}{|c|}{0.380} & \multicolumn{2}{|c|}{0.387} \\
\hline
\end{tabular}

$\aleph^{*}, * *, * *$ are significant at a $10 \%, 5 \%$, and $1 \%$ level, respectively. See research model to identify operational definition of variable. 


\section{CONCLUSION}

Prior research suggests that the existence of debt provides a monitoring function for borrowers and reduces the agency costs of equity. However, other studies report that there is a possibility for earnings management even if the borrowings from financial institutions are high, inducing the monitoring of firms.

Therefore, this study investigates whether or not short-term debt is related to earnings management. Short-term debt is divided into total current liabilities, debt in current liabilities and short-term borrowings. In addition, this study examines how short-term debt is related to how firms manage earnings. I use discretionary accruals and real operating decisions as the earnings management method.

The study finds that total current liabilities have a statistically insignificant impact on accrual earnings management and real earnings management. Debt included in current liabilities only has a statistically significant impact on accrual earnings management, and short-term borrowings are only shown to have a statistically significant impact on real earnings management. These results indicate that managers engage in accrual earnings management of debt included in current liabilities and use real earnings management of short-term borrowings from financial institutions.

In addition, abnormal CFO, abnormal production costs, and abnormal discretionary expenses are used as proxies for real earnings management. The coefficient on short-term borrowings is negative and significant in the abnormal CFO model, and the coefficient on total current liabilities is positive and significant in the abnormal production costs model. Finally, the coefficient on short-term borrowings is positive and significant in the abnormal discretionary expenses model. These results indicate that firms may engage in real earnings management to report adjusted earnings.

Therefore, this evidence indicates that firms engage in accrual earnings management of debt in included current liabilities when they face the liquidity risk of short-term debt, and firms with debt financing constraints are likely to manage real earnings in spite of enhanced firm monitoring by lenders such as financial institutions.

The findings in this study may have implications in the debate about the monitoring function of financial institutions such as banks. Future research may re-examine how firms manage their accrual or real earnings in mid- or long-term debt financing.

\section{ACKNOWLEDGEMENTS}

This work was supported by the National Research Foundation of Korea Grant funded by the Korean Government (NRF-2014S1A2A1A01027404)

\section{AUTHOR BIOGRAPHY}

Sun-young Park is an associate professor at Business School, Kyungpook National University, South Korea. She received her Ph.D. from Kyungpook National University. Her research areas include intangible investment, earnings management, and firm's performance. E-mail: parksysy@knu.ac.kr

\section{REFERENCES}

Ahn, H. B. (2004), The empirical study on relationship of firm's governance-owner structure and earnings management, Korean Accounting Review, 29(4), 117-154.

Ashbaugh, H., R. LaFond \& B. W. Mayhew (2003), Do nonaudit services compromise auditor independence? Further evidence, The Accounting Review, 78(3), 611-639.

Barclay, M. J. \& C. W. Smith, Jr. (1995), The maturity structure of corporate debt, Journal of Finance, 50(2), 609-632.

Becker, C. L., M. L. DeFond, J. Jiambalvo \& K. R. Subramanyam (1998), The effect of audit quality on earnings management, Contemporary Accounting Research, 15, 1-24.

Beneish, M. D. \& E. Press (1993), Costs of technical violation of accounting-based debt covenants, The Accounting Review, 68(2), 233-257. 
Bharath, S. T., J. Sunder \& S. V. Sunder (2008), Accounting quality and debt contracting, The Accounting Review, 83(1), 1-28. Bhattacharya, S. \& G. Chiesa (1995), Proprietary information, financial intermediation, and research incentives, Journal of Financial Intermediation, 4(4), 328-357.

Chemmanur, T. J. \& P. Fulghieri (1994), Reputation, renegotiation and the choice between bank loans and publicly traded debt, Review of Financial Studies, 7(3), 475-506.

Cohen, D. A., A. Dey \& T. Z. Lys (2008), Real and accrual based earnings management in the pre- and post-Sarbanes-Oxley periods, The Accounting Review, 83, 757-787.

Cohen, D. A. \& P. Zarowin (2008), Accrual-based and real earnings management activities around seasoned equity offerings, Working paper. New York University.

DeAngelo, H., L. DeAngelo \& D. Skinner (1994), Accounting choice in troubled companies, Journal of Accounting and Economics, 14, 113-144.

Dechow, P. M., R. G. Sloan \& A. P. Sweeney (1995), Detecting Earnings Management, The Accounting Review, 70, $193-225$.

DeFond, M. L. \& J. Jiambalvo (1994), Debt covenant violation and manipulation of accruals, Journal of Accounting and Economics, 17, 145-176.

DeFond, M. L. \& C. W. Park (1997), Smoothing income in anticipation of future earnings, Journal of Accounting and Economics, 23, 115-139.

DeFond, M. L. \& K. Subramanyam (1998), Auditor changes and discretionary accruals, Journal of Accounting and Economics, 25(1), 35-68.

Diamond, D. W. (1984), Financial intermediation and delegated monitoring, Review of Economic Studies, 51, 393-414.

Diamond, D. W. (2004), Presidential address, committing to commit: Short-term debt when enforcement is costly, Journal of Finance, 59(4), 1447-1479.

Fama, E. F. (1985), What's different about banks?, Journal of Monetary Economics, 15(1), 29-39.

Flannery, E. F. (1986), Asymmetric information and risky debt maturity choice, Journal of Finance, 41(1), 18-38.

Fung, S.Y.K. \& J. Goodwin (2013), Short-term debt maturity, monitoring and accruals-based earnings management, Journal of Contemporary Accounting \& Economics, 9, 67-82.

Gertner, R. H., D. S. Scharfstein \& J. C. Stein (1994), Internal versus external capital markets, Journal of Economics, 109(4), 1211-1230.

Gunny, K. (2006), What are the consequences of real earnings management?, Working paper, University of Colorado.

Gupta, M. \& L. P. Fields (2006), Debt maturity structure and earnings management, Working Paper, Southern Illinois University and Texas A\&M University.

Healy, P. M. \& K. G. Palepu (1990), Effectiveness of accounting-based dividends covenants, Journal of Accounting and Economics, 12(1-3), 97-123.

Holthausen, R. W. \& R. W. Leftwich (1983), The economic consequences of accounting choice implications of costly contracting and monitoring, Journal of Accounting and Economics, 5(1), 77-177.

Jensen, M. C. \& W. H. Meckling (1976), Theory of the firm: Managerial behavior, agency costs and ownership structure, Journal of Financial Economics, 17, 305-360.

Kim, E. Y. \& S. Y. Park (2014), Financial institute debt maturity and earnings management, Journal of Business Research, 29(1), 191-221.

Kothari, S. P., A. J. Leone \& C. E. Wasley (2005), Performance matched discretionary accrual measures, Journal of Accounting and Economics, 39(1), 163-197.

La Porta, R., F. Lopez de Silances, A. Shleifer \& R. Vishny (2000), Investor protection and corporate governance, Journal of Financial Economics, 58(1-2), 2-27.

Moon, H. (2007), A relation among debt ratio, variance of profits and discretionary accruals, Korea Journal of Business Administration, 20(4), 1647-1666.

Myers, J. N, L. A. Myers \& T. C. Omer (2003), Exploring the term of the auditor-client relationship and the quality of earnings: A case for mandatory auditor rotation?, The Accounting Review, 78(3), 779-799.

Paek, W. \& K. Choi (1999), Earnings management and incentive for minimizing corporate income taxes, Korean Accounting Review, 24(1), 115-140.

Park, J. (2003), Corporate governance and earnings management: View from the largest shareholder's holding, Korean Accounting Review, 28(2), 135-173.

Park, S. (2001), Study on the determinants of debt maturity structure of listed Manufacturing companies in different firm size, Korean Journal of Financial Management, 18(3), 27-73.

Park, S., J. Jang, G. Jung \& S. Bae (2006), An empirical study on the relationship between corporate governance and earnings management, Accounting Information Review, 24(1), 213-241.

Rajan, R. \& A. Winton (1995), Covenants and collateral as incentives to monitor, Journal of Finance, 50(4), $1113-1146$.

Roychowdhury, S. (2006), Earnings management through real activities manipulation, Journal of Accounting and Economics, 42, 335-370.

Scherr, F. C. \& H. M. Hulburt (2001), The debt maturity structure of small firms, Financial Management, 30(1), 85-111.

Schipper, K. (1989), Commentary on earnings management, Accounting Horizons, 3(4), 91-102. 
Skinner, D. J. \& R. G. Sloan (2002), Earnings surprises, growth expectations, and stock returns or don't let an earnings torpedo sink your portfolio, Review of Accounting Studies, 7(2-3), 289-312.

Smith, C. (1986), Investment banking and the capital acquisition process, Journal of Financial Economics, 15, 3-29.

Stohs, M. H. \& D. C. Mauer (1996), The determinants of corporate debt maturity structure, Journal of Business, 69(3), 279-312.

Stulz, R. (1990), Managerial discretion and optimal financing policies, Journal of Financial Economics, 26, 3-27.

Subramanyam, K. R. (1996), The pricing of discretionary accruals, Journal of Accounting and Economics, 22(1), $249-281$.

Sweeney, A. P. (1994), Debt-covenant violations and managers, accounting responses, Journal of Accounting and Economics, 17(3), 281-308.

Warfield, T. D., J. J. Wild \& K. L. Wild (1995), Managerial ownership, accounting choice, and informativeness of earnings, Journal of Accounting and Economics, 38(4), 431-456.

Watts, R. L. \& J. L. Zimmerman (1990), Positive accounting theory: A ten year perspective, The Accounting Review, 65(1), 131156.

Yoon, S. (2001), A comparison of earnings management between KSE firms and KOSDAQ firms, Korean Journal of Financial Studies, 29, 57-85.

Zang, A. (2006), Evidence on the tradeoff between real manipulation and accrual manipulation, Working paper, University of Rochester. 